Article

\title{
Analysis of Mining-Induced Delayed Surface Subsidence
}

\author{
Krzysztof Tajduś $^{1}\left(\mathbb{D}\right.$, Anton Sroka ${ }^{1}$, Rafał Misa ${ }^{1}\left(\mathbb{D}\right.$, Stefan Hager ${ }^{2}$, Janusz Rusek ${ }^{3} \mathbb{D}$, Mateusz Dudek $^{1, *(\mathbb{D})}$ \\ and Frank Wollnik ${ }^{2}$ \\ 1 Instytut Mechaniki Górotworu PAN, ul. Reymonta 27, 30-059 Kraków, Poland; tajdus@imgpan.pl (K.T.); \\ sroka@imgpan.pl (A.S.); misa@imgpan.pl (R.M.) \\ 2 RAG Aktiengesellschaft, Im Welterbe 10, 45141 Essen, Germany; stefan.hager@rag.de (S.H.); \\ frank.wollnik@rag.de (F.W.) \\ 3 Faculty of Mining Surveying and Environmental Engineering, AGH University of Science and Technology, \\ Al. A. Mickiewicza 30, 30-059 Kraków, Poland; rusek@agh.edu.pl \\ * Correspondence: dudek@imgpan.pl; Tel.: +48-12-637-62-00
}

check for updates

Citation: Tajduś, K.; Sroka, A.; Misa, R.; Hager, S.; Rusek, J.; Dudek, M.; Wollnik, F. Analysis of Mining-Induced Delayed Surface Subsidence. Minerals 2021, 11, 1187. https://doi.org/10.3390/min11111187

Academic Editor: Javier Fernández Lozano

Received: 11 October 2021

Accepted: 22 October 2021

Published: 26 October 2021

Publisher's Note: MDPI stays neutral with regard to jurisdictional claims in published maps and institutional affiliations.

Copyright: (c) 2021 by the authors. Licensee MDPI, Basel, Switzerland. This article is an open access article distributed under the terms and conditions of the Creative Commons Attribution (CC BY) license (https:// creativecommons.org/licenses/by/ $4.0 /)$.

\begin{abstract}
The topic of residual subsidence is important in Europe as it defines possible surface deformation for closed mine areas. It has to be determined because of potential financial claims and damages of sensitive objects such as satellite dishes, precision mechanics objects, agriculture, forestry and hydrogeology, etc. Analyses of measured subsidence after the end of mining exploitation indicate that this process can last from several months to several dozen or even several hundred years, and the final surface subsidence is not known. It is dependent on the individual's features of excavated medium, depth of exploitation, a system of exploitation, behaviour of surrounding rock masses, etc. In the article, the authors analysed the assessment of the subsidence process after the end of mining operations, based on the innovative method. This concerns the duration of the subsidence process and the size of the expected subsidence. The methodology was applied to the RAG Aktiengesellschaft company project where prognostic calculations were made for seven closed coal mines using unique results of precise height measurements carried out for more than 90 years by the German State Office for National Measurements (Landesvermessungsamt NRW) under the so-called levelling measurements net. These measurements are carried out every 2 years and serve to keep the altitude network in the whole state of Rhineland Westphalia up-to-date. The result of the prognosis for one case study, German mine Auguste-Victoria, is presented in the article.
\end{abstract}

Keywords: residual subsidence; mining closure; environment; mining deformation

\section{Introduction}

It is an undeniable fact that underground mining operations have degraded the environment over the past decades, despite various attempts to minimise their impact [1-3]. From a rock mechanics point of view, the exploitation leads to changes in the original state of stress and deformations in the rock mass [4,5]. One of the most typical forms of such changes is the continuous deformation of the surface, which takes the form of land subsidence. Additionally, it has a significant impact by affecting the reliability of the surrounding land and infrastructure. Over the last century, many methods and theories have been developed to predict mining surface deformations during the extraction of the deposit, i.e., [6-10]. However, these works mainly encompass the problem of deformation during the ongoing mining operation, because at this stage, it has the strongest impact on changing the landscape of the area (terrain and water conditions). In the United States, shallow mining at the depth of ca. 300-400 m below ground level in many places has led to a change in the function of land use [11]. Numerous former pastures have been turned into floodplains as a result of creating large regional subsidence basins and their subsequent flooding. In Europe, due to the location of mining in highly urbanised areas, this problem is mainly related to the occurrence of mining damage to building structures. Usually, this 
includes damage to residential buildings, outages of transmission networks, and damage to transport facilities (roads, railways), e.g., [12,13].

Contrary to popular belief, the problem of deformation of the rock mass and the ground surface does not end when exploitation ends [14]. At the beginning of the 20th century, there were changes in how the exploitation of deposits was conducted (especially multi-seam exploitation and with roof collapse). The mining moved to greater depths (even more than $1000 \mathrm{~m}$ ), which over the years led to the formation of hundreds of goafs in the rock mass, i.e., post-mining spaces partially filled with rock material, the compaction of which can be observed long after the mining ends.

The measurements of subsidence usually concern short-term observations of one longwall panel or a set of panels or long-term observations of the entire coal basin. Shortterm measurements are usually carried out as part of the ongoing monitoring of the impact of mining on surface infrastructure facilities and typically end between 0.5 and 1 year after the end of a mining operation. The decision to end the observations is based on various criteria, based on many years of experience. In Poland, for example, it was assumed that the impact ceases when the annual increase in subsidence is less than $1.0 \mathrm{~cm}$; in Germany, this is covering its liability for damage which can be reported up to 3 years after the end of the mining operation. In China, this period ends if there is less than $0.3 \mathrm{~cm}$ of accumulated surface subsidence during a period of six months, which indicates a stabilised surface movement [6]. The same term was adopted for measurements in Ukraine. In Russia, the last series of measurements are carried out if the subsidence does not exceed $10 \mathrm{~mm}$ within 6 months.

Long-term observations of the whole coal basin, covering even several dozen mines, have been carried out to this day in the form of precise levelling for over a hundred years, and in the last period, usually every two years (e.g., Ruhr Basin).

Finding the limit value and the moment at which the impact ceases is important for the assessment of the disturbances in the environment and the provisions of the Mining and Geological Law, which says that at the end of the exploitation, the owner is obliged to restore the land to the state that is as close as possible to its original state, allowing its further use. In the event of successive mine closures [15], the issue of reclamation and revitalisation of land and its costs is important [16]. Depending on the level of degradation, it is possible to give this land a new purpose and utility function, e.g., recreational, agricultural, residential, or commercial. The new opportunities, depending on the application, may become possible for local communities, by acquiring new investments, jobs, the inflow of inhabitants, funds to the budgets of municipalities/cities, or increasing the popularity among tourists. However, for this purpose, it is also important to know about the further impact of mining on the land surface. Based on the results of geodetic measurements of surface subsidence carried out during the operation of the RAG mines and after its closure (31 December 2015), the authors proposed a solution enabling the calculation of residual subsidence of the land surface. This solution makes it possible to determine both the final amount of subsidence and the approximate time at which the deformation value assumed as the limit for residual subsidence is achieved.

\section{Experiments with the Determination of Residual Surface Deformations at the End of Underground Exploitation}

Initially, it was generally assumed that surface movement caused by underground mining could be divided into two stages: active subsidence and residual or delayed subsidence. The latter is related to the direct exploitation and reaction of the rock mass. They are recorded with a possible delay [17] and represent about $80-90 \%$ of the final subsidence level. The former, i.e., residual subsidence, occurs over a long period of time after the end of exploitation. This division was then extended to three stages $[18,19]$. The stage of active subsidence was divided into the following: preliminary subsidence (phase I), in which from $5 \%$ to $15 \%$ of final subsidence is observed, and main subsidence (also called accelerated) (phase II), in which from $70 \%$ to $90 \%$ of final subsidence is observed. Stage III 
contains the residual subsidence mentioned above (Figure 1), which might range from $1 \%$ to $10 \%$ of the final subsidence.

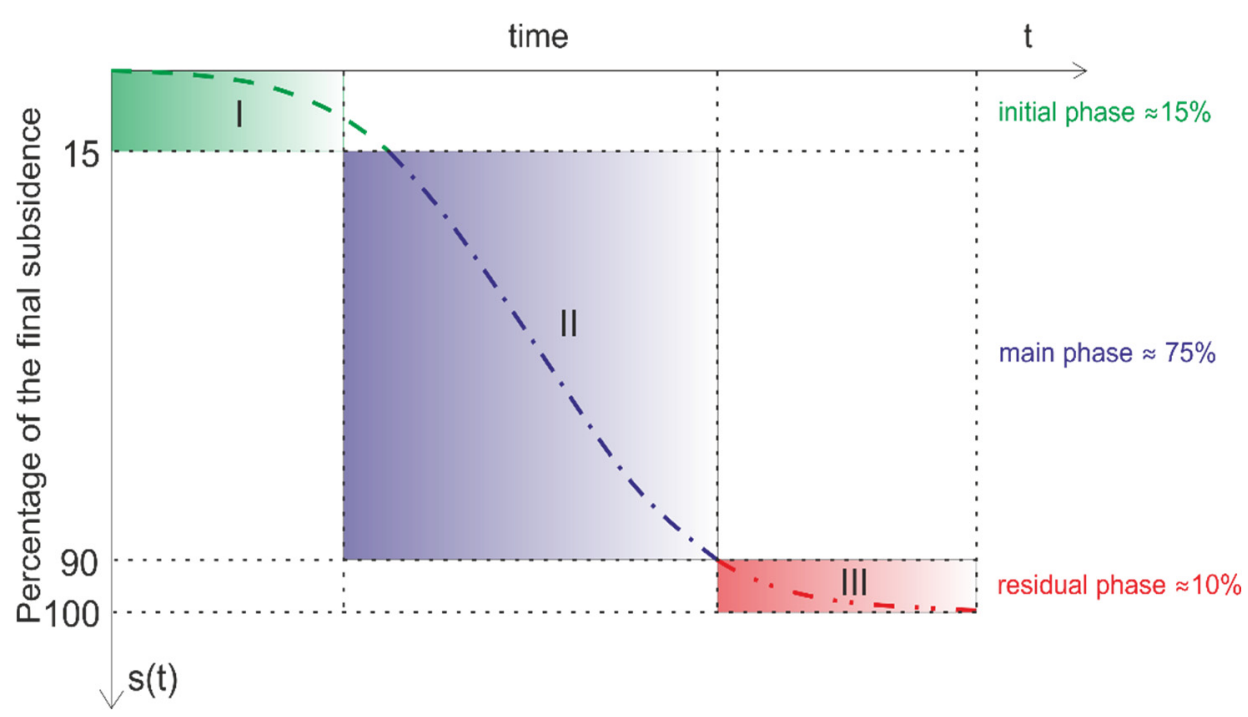

Figure 1. Sketch map of subsidence development for a surface point.

It is generally accepted that during the lifespan of a mine, the surface subsidence measurements are carried out up to a maximum of one year after the end of its exploitation, which is also provided in the regulations [20]. This is because a large part of the residual subsidence-from $40 \%$ to $80 \%$-appears at the end of the first year [19]. In the following years, the rate of subsidence decreases significantly. It is a brief period in the analysis of residual subsidence, the influence of which may be evident for decades. It is caused by the process of convergence of goafs and the related phase of long-term reconsolidation. Back when the mines existed and operated, the topic of residual subsidence was omitted, which led to a lack of general knowledge in this area. The situation changed along with the process of closing mines. According to Hoek [21] currently, residual subsidence is one of the main problems related to closed mines because the difficulty of determining its duration significantly affects the assessment of environmental degradation and construction problems. The period in which the occurrence of subsidence is possible varies depending on many factors. These include methods of exploitation, backfilling, the intensity of exploitation in the area, the strength of coal, roof and floor, the range and intensity of cracking in the rock mass, rock bulking, the number of water inflows, depth of exploitation, the existence of faults, seam tilt, and speed of exploitation-to list a few. For example, for partial exploitation, such as the room and pillar system, this time depends on the temporary strength of the pillars and can be postponed until the pillar is destroyed and the roof collapses. Examples can be found in works describing this phenomenon, among others: [22,23].

One of the more interesting works on the level and duration of residual subsidence after the closure of a coal mine is the paper by Vervoort and Declercq [24]. Based on subsidence measurements, the authors conducted an extensive analysis of the changes existing at the surface, long after the Houthalen mine was closed in Belgium. In this area, the total thickness of exploited seams ranged from 2.8 to $9.9 \mathrm{~m}$, with the thickness of individual seams ranging from 1 to $2 \mathrm{~m}$. Their tilt varied from $9^{\circ}$ to $24^{\circ}$, and the mining took place between the years 1939 and 1968, but most of the longwalls were mined in the years 1940-1960. Observations showed that even 40-60 years after the extraction ended, subsidence still occurs and can be measured. The level of residual subsidence ranged from 2.8 to $8.7 \mathrm{~mm}$ /year (5.5 mm/year on average) and reached a maximum of $72.2 \mathrm{~mm}$ (average $45.5 \mathrm{~mm}$ ). This process was disrupted after 2000 when the process of sinking the mine began. It caused both an acceleration and change in the character of how the terrain surface deformed, with the region being partially raised at an average speed of 
$18 \mathrm{~mm} /$ year and partially lowered by $16 \mathrm{~mm} /$ year. Similar conclusions as to the duration of residual subsidence were presented, among others by Keinhorst [8] and Niemczyk [25].

Other conclusions from observing the duration of residual subsidence were presented by Flaschentrager [26], suggesting that for the area of the left Lower Rhine, the subsidence process practically ends about six months after the cessation of mining. These results were confirmed by Czubik [27] and Knufinke [28]. The in situ measurements showed that one month after the end of exploitation, about $50 \%$ of the expected subsidence took place, after two months $75 \%$, after three $87 \%$, after four $93 \%$, after five $97 \%$, and after six months about $100 \%$.

Blachowski and his team [29], Głowacki, Milczarek [30], Schäfer [31], and Lein [32] drew other conclusions based on satellite measurements (mainly InSAR), from which they determined the duration of surface movements to range from five to a maximum of ten years after the end of exploitation. Similar conclusions were presented in the report from the Bureau of Land Management USDI [33], which concluded that the duration of residual deformations over longwall operations is relatively short and ranges from a few weeks to 10 years. Studies carried out for the mining region of France have shown that during the last two or three years of the residual subsidence phase, the amplitude of subsidence is negligible [19]. In the Nord and Pas-de-Calais area (France), where mining was discontinued in December 1990, the existing measurement points showed different behaviours over time, but all showed an overall decline in subsidence in the years 1992-1999. In fact, from the end of 1992 to 1996, they all subsided by an additional $4 \mathrm{~cm}$ in the Courrières area and by $2 \mathrm{~cm}$ in Billy-Montigny [19] (the rate of subsidence $S_{t}$ was $1.25 \mathrm{~cm}$ /year on average). On the other hand, no further deformations were observed in the Courrières area after 1996, which shows that the area is stable or that the registered deformation amplitude was below the detection threshold of the DINSar method used (about $0.3 \mathrm{~cm} /$ year). On the other hand, both the Lens and Billy-Montigny areas continued to show small movements from 1996 to 1999 , while the rates of subsidence $S_{t}$ were reduced for Lens from 1.2 to $0.7 \mathrm{~cm} /$ year and for Billy-Montigny from 0.8 to $0.5 \mathrm{~cm} /$ year. The conducted interferograms (Envisat) for the period 2004-2007 confirmed the absence of a significant signal from Courrières, while the Lens and Billy-Montigny regions showed an additional reduction of ca. $0.3 \mathrm{~cm}$ per year. In the Marienau region (Lorraine coal basin, France), the total residual subsidence is between 20 and $55 \mathrm{~cm}$, and the stabilisation period was less than two years, while the location of the maximum residual subsidence occurs at a distance of $700 \mathrm{~m}$ from the location of the maximum level of subsidence related to phases I and II [18]. In this example, the residual subsidence value is equal to $5 \%$ of the maximum subsidence value. However, it should be noted that in the presented case, the residual tilt of the land surface is at $0.2 \%$ of the maximum value of Tmax, and the total tilt increased from $1.8 \%$ (before the residual subsidence phase) to $2 \%$ (after the residual subsidence phase) [34], which, in the case of fixed values of the mining area category indexes, may in some cases show that the predetermined category is exceeded [35].

There are similar results of displacement measurements carried out for the city of Bytom (Poland) [36], where multi-seam mining was carried out for years in the safety pillar. In total, the coal mine KWK Centrum exploited the deposit in this area to a total thickness of up to $30 \mathrm{~m}$. In April 2015, the mine ceased its operations, which had lasted (under various names) since the 1950s. The last exploitation in the midtown pillar was carried out in the seam 510 with a longwall system and a hydraulic backfill of a height of $2.4 \mathrm{~m}$. The depth of the exploitation was $650 \mathrm{~m}$ with the $140 \mathrm{~m}$ front width. In the period from May 2015 to September 2018, the measured subsidence in the area of the last exploitation generally ranged from 2.5 to $27.2 \mathrm{~mm}$. When analysing the last three years after the end of the operation, the annual reduction increments ranged from $+2.9 \mathrm{~mm}$ (uplift) to $-4.2 \mathrm{~mm}$ (subsidence). In the last year, the subsidence was between 0.2 and $3.0 \mathrm{~mm}$. These observations led to the conclusion that this area, which was influenced by many years of underground mining, could be considered stable in two years after the mining operations had ended. It is estimated that the subsidence of the mining area after 
the end of exploitation will still be seen with values of $\pm 1 \mathrm{~mm} /$ year. However, they will not affect building structures. Table 1 shows additional data on the duration and amplitude of phase III related to residual subsidence.

Table 1. Duration and amplitude of residual subsidence phase [18,37].

\begin{tabular}{|c|c|c|}
\hline Cases & Mining Conditions & Residual Subsidence \\
\hline UK (Many basins) & Long-wall method and plastic layers & $\begin{array}{l}\text { Less than } 12 \text { months: } 5-6 \% \text { of } \\
\text { total subsidence }\end{array}$ \\
\hline UK (Durham Coalfield) & Two mines with high-resistance strata & $\begin{array}{c}8 \% \text { of total subsidence after } 4 \text { years and } \\
9 \% \text { after } 6 \text { years, and } 6-8 \% \text { of total } \\
\text { subsidence after } 4 \text { years }\end{array}$ \\
\hline West Germany & Long-wall method used by many mines & 5 years with $75 \%$ from the first year \\
\hline Australia & Long-wall with caving method & 3 to 7 months \\
\hline \multirow[t]{2}{*}{ India } & Long-wall method in virgin ground & $\begin{array}{l}\text { 10-15 months for } 10-30 \% \text { of } \\
\text { total subsidence }\end{array}$ \\
\hline & Long-wall method in already extracted zones & $2-4$ months for $5-10 \%$ of total subsidence \\
\hline USA & Long-wall method & $\begin{array}{l}10 \% \text { of total subsidence: } 1 \text { month and } \\
12 \% \text { after } 17 \text { months }\end{array}$ \\
\hline $\begin{array}{l}\text { France (Nord-Pas-de-Calais, } \\
\text { Albi-Carmaux) }\end{array}$ & Plastic strata in already extracted zones & $99 \%$ of total subsidence after $3-4$ years \\
\hline $\begin{array}{c}\text { France (Provence, Lorraine, } \\
\text { and Blanzy) }\end{array}$ & Resistant strata in already extracted zones & $2-3$ years \\
\hline
\end{tabular}

\section{Methods of Forecasting the Residual Subsidence Value after Exploitation Ends}

As shown in the above experiences of worldwide scientists, discrepancies in the duration of residual subsidence are highly significant. Unfortunately, this problem is often overlooked in the course of mining operations due to its low percentage value compared to deformations originating from phase I or II subsidence, or the problem of determining residual deformations with overlapping (superposition principle) influences from progressive mining. In turn, after the mines are closed, this problem is often neglected by local government authorities, such as the situation in South Korea presented by Lee [38]. It is therefore important to have the appropriate tools to predict future residual subsidence.

Several scientists from all over the world have dealt with the topic of residual subsidence forecasts in their work. One of the earliest was Professor Knothe [39], who in the 1950s presented a solution for determining the time function $z(t)$ in the form:

$$
\dot{s}(t)=c\left[s_{k}(t)-s(t)\right] z(t)=1-\exp (-c t),
$$

where $\dot{s}(t)$ is the momentary speed of subsidence, $c$ is the time factor, $s_{k}(t)$ is the final subsidence of the point with the assumption of the exploitation end in time $t, s(t)$ is the real value of subsidence, $z(t)$ is the function of time, and $t$ is time.

In the following years, similar work was carried out by Trojanowski [40]. A twoparameter model of the time function was presented by Schober and Sroka [41] describing the process of subsidence above salt caverns, whereas Sroka's [42] solution is empirical. In 2013, Liu Xinrong [43] presented a method of forecasting land surface subsidence based on the new time function method, taking account of the dynamic process, the velocity change process, and the acceleration change process during surface subsidence. The use of this solution showed that it predicts values higher than the measured ones and was applied to subsidence with a duration of up to 30 months, i.e., mainly related to phase I and II, rather than to phase III, i.e., residual, long-term subsidence. A similar solution was presented in the article by $\mathrm{Hu}$ [44], where authors tried to determine the value of the time factor $c$ of Knothe's function, which relates only to the active subsidence process [45-47]. 
Cui [48] presented an interesting solution showing the possibility of determining future residual subsidence at the end of the exploitation process. According to the solution presented in the paper, the annual residual subsidence coefficient $\left(a_{A}^{t}\right)$ can be calculated using the equation:

$$
a_{A}^{t}=k(1-a)\left(1-e^{-\left(\frac{50-t}{50}\right)}\right)
$$

where $a$ is the surface subsidence factor (ranging from 0.65 to 0.90 in China), $k$ is a coefficient related to the compaction of goaf, which is between 0.5 and 1.0, and $t$ is the time after the end of extraction.

According to Equation (2), for the time span $t=50$ years, the annual residual subsidence $a_{A}^{t}$ is reduced to 0 .

On the other hand, Sroka $[45,49]$ proposed a eaquation to describe the subsidence in time at the end of Exploitation (3):

$$
s(t>T)=s(T)+\left[s_{e}(T)-s(T)\right][1-\exp (-c(t-T))]==s_{e}(T)-\Delta s_{e}(T) \cdot \exp (-c(t-T)),
$$

where $T$ is the end time of exploitation in the area, $s(T)$ is subsidence in time $T, s_{e}(T)$ is total final subsidence, $\Delta s_{e}(T)$ is the expected increase in subsidence after the end of the time of exploitation in time $T$, and $t$ is the year for which subsidence is calculated.

There is a relationship between $s(T), s_{e}(T)$, and $\Delta s_{e}(T)$, which is schematically presented in Figure 2: $s_{e}(T)=s(T)+\Delta s_{e}(T)$.

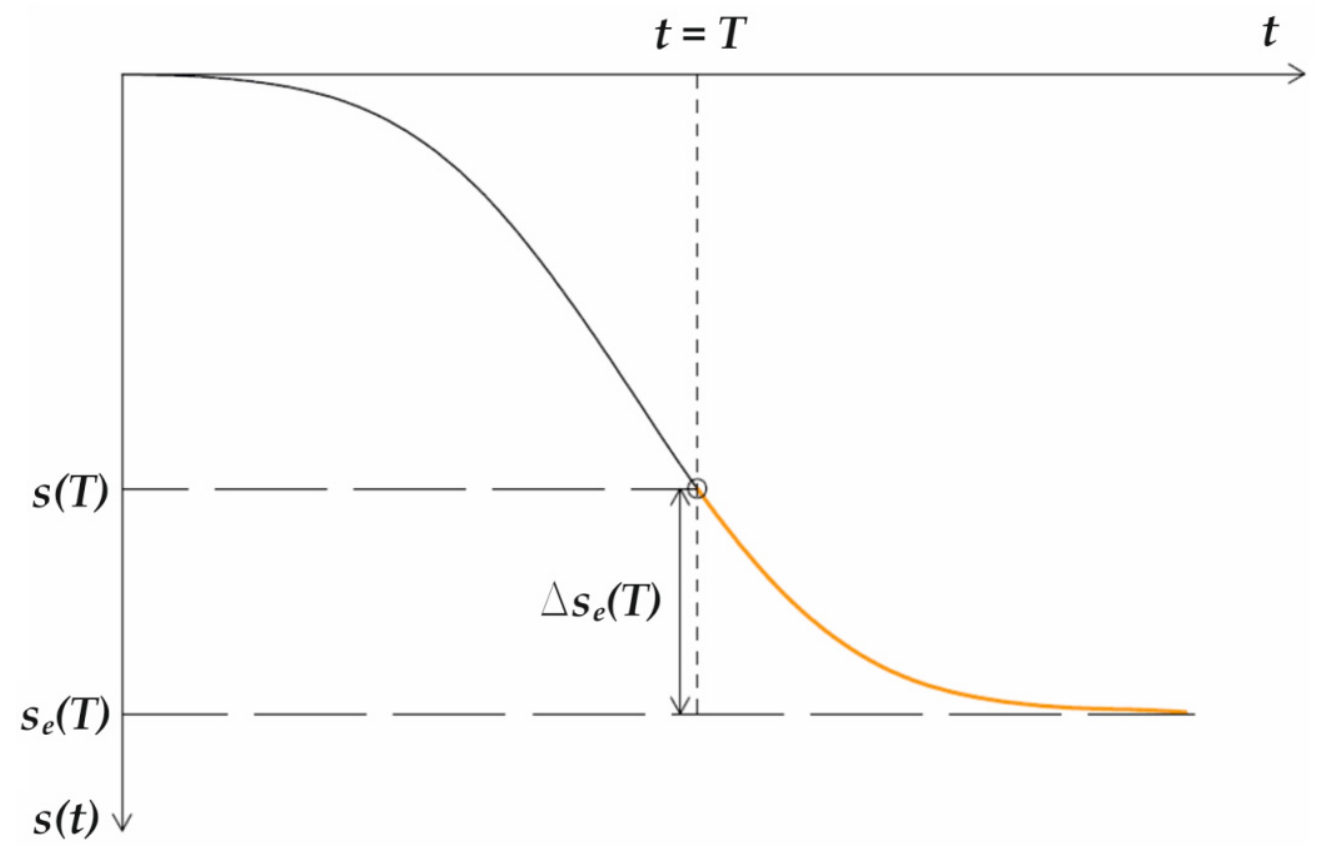

Figure 2. Subsidence after the end of exploitation in time $T$.

\section{Methods of Forecasting Residual Subsidence}

The observations conducted for the areas of closed underground mines covered by the measurements showed that the subsidence after the end of exploitation is described by means of an exponential, asymptotic function aimed at the expected value of the final subsidence. These observations, together with analyses of the recorded displacements during exploitation, made it possible to develop a three- or four-point solution enabling one to forecast future values of final residual subsidence and determine the time span to achieve the limit value of residual subsidence $\Delta s_{G r}$, i.e., the level of subsidence significant for the future use of the land (Figure 5) [50]. The three- or four-point solution is selected depending on the length of the measurement period, the number of measurement points that can be used, and the course of exploitation. 
For the three-point solution, the same interval between measurements is assumed, i.e., $t_{3}-t_{2}=t_{2}-t_{1}=\Delta t$. The subsidence diagram for the three-point solution is shown in Figure 3.

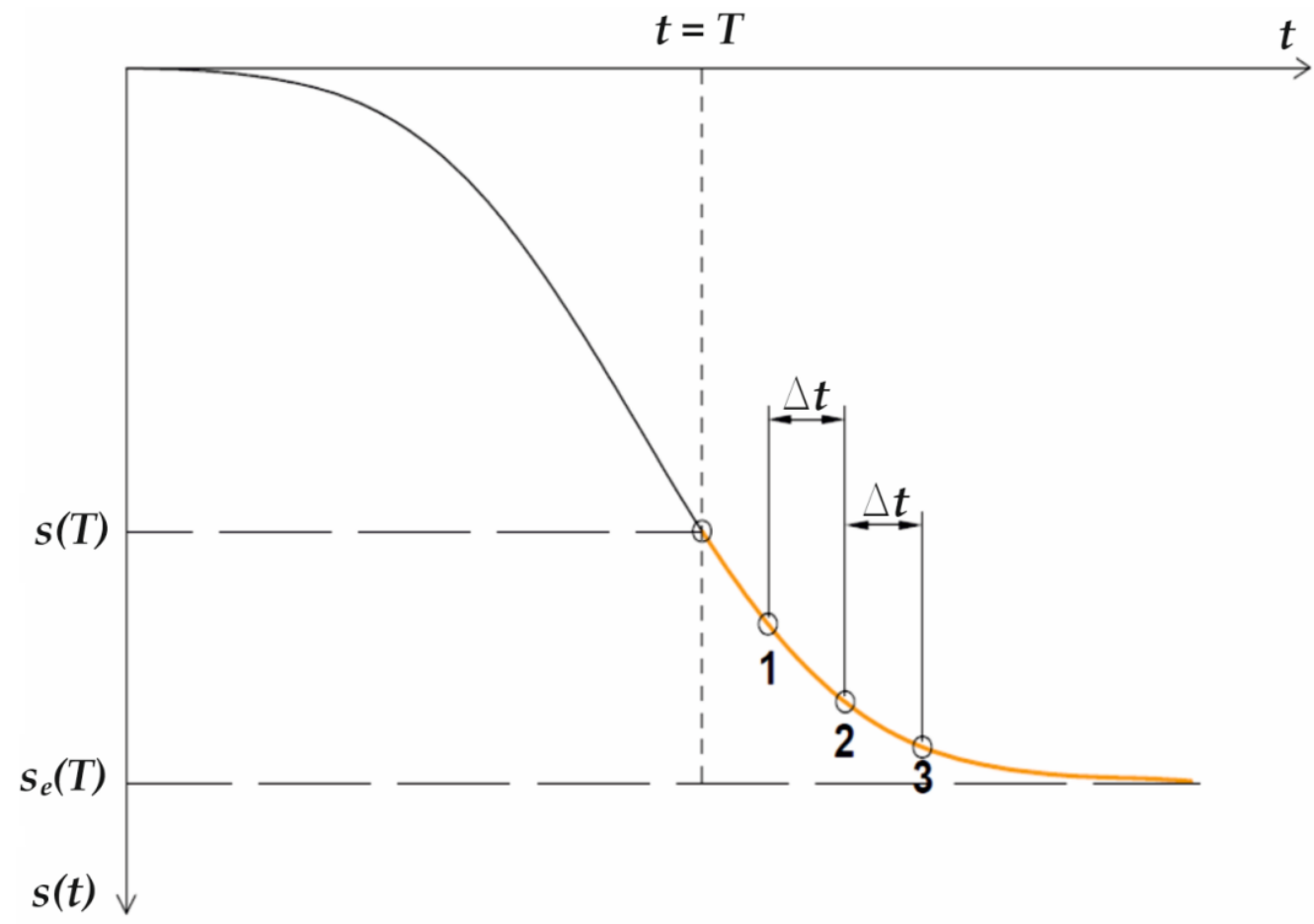

Figure 3. Subsidence calculation method for the three-point solution.

The final subsidence in time $\left(s_{e}\right)$ can be calculated from equation:

$$
s_{e}=\frac{s_{2}^{2}-s_{3} s_{1}}{2 s_{2}-\left(s_{3}+s_{1}\right)}
$$

where $s_{1}, s_{2}$, and $s_{3}$ are the individual levels of subsidence for the measured point at equal intervals.

The time factor $c$ is determined by Equation (5):

$$
c=-\frac{1}{\Delta t} \ln \frac{s_{3}-s_{2}}{s_{2}-s_{1}}
$$

where $\Delta t$ is the interval between measurements $t_{3}-t_{2}=t_{2}-t_{1}$.

For the presented three-point solution, the authors determined the value of standard deviation for subsidence in time with Equation (6):

$$
s_{s_{e}}=\frac{s_{s}}{2 s_{2}-\left(s_{1}+s_{3}\right)} \sqrt{\left(s_{e}-s_{1}\right)^{2}+4\left(s_{e}-s_{2}\right)^{2}+\left(s_{e}-s_{3}\right)^{2}},
$$

where $s_{s}$ is the accuracy of subsidence measurement (standard deviation), and the value of standard deviation for time factor $c$ is the one in Equation (7):

$$
s_{c}=\frac{s_{s}}{\Delta t} \sqrt{\frac{1}{\left(s_{2}-s_{1}\right)^{2}}+\frac{1}{\left(s_{3}-s_{2}\right)^{2}}+\frac{\left(s_{3}-s_{1}\right)^{2}}{\left(s_{2}-s_{1}\right)^{2} \cdot\left(s_{3}-s_{2}\right)^{2}}}
$$

the four-point solution assumes the same interval between measurements, i.e., $t_{4}-t_{3}=$ $t_{2}-t_{1}=\Delta t$. This situation is illustrated in Figure 4 . 


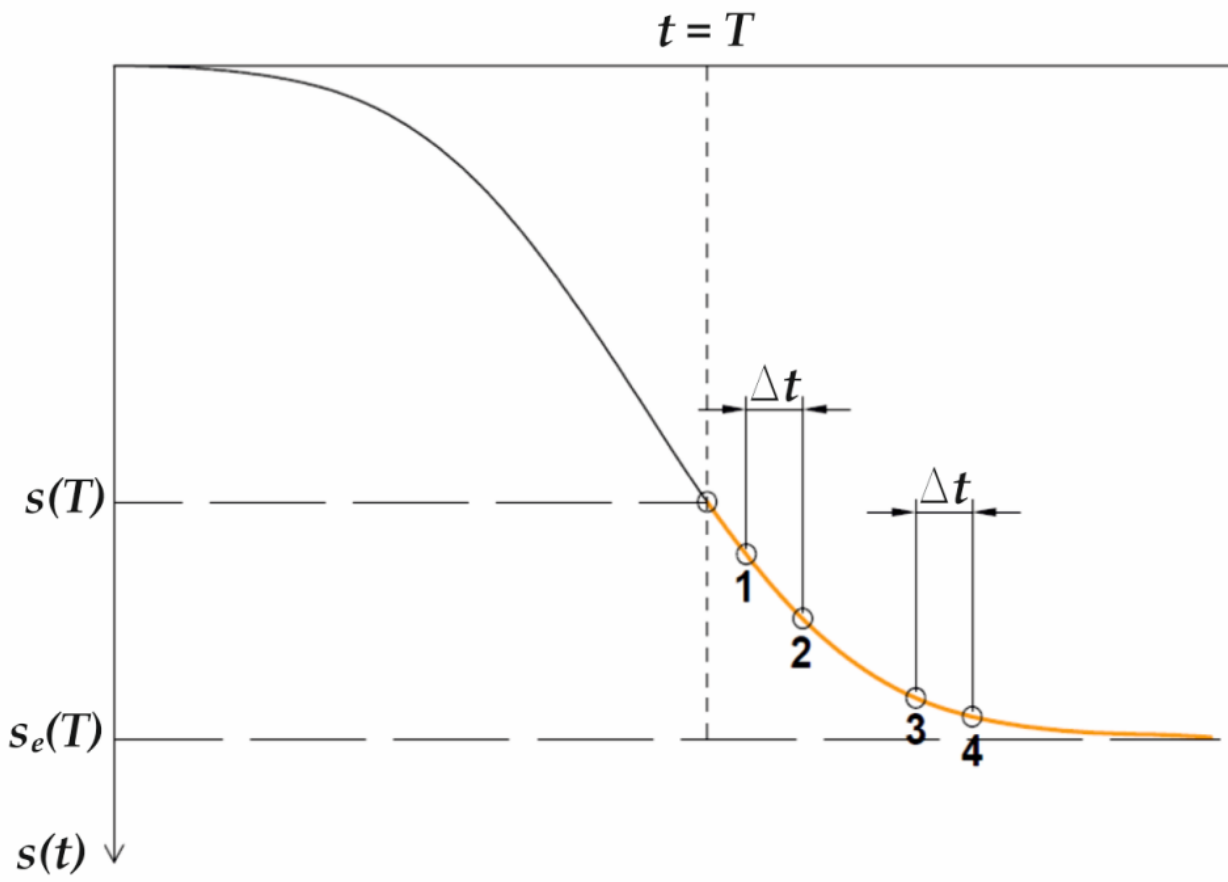

Figure 4. Subsidence calculation method for the four-point solution.

In this solution, the following Equation (8) is used to calculate the final subsidence in time $\left(s_{e}\right)$ :

$$
s_{e}=\frac{s_{3} s_{2}-s_{4} s_{1}}{\left(s_{3}+s_{2}\right)-\left(s_{4}+s_{1}\right)}
$$

However, similarly as in the solution in Equation (5), the time factor for the four-point solution takes the following equation:

$$
c=-\frac{1}{\Delta t} \ln \frac{s_{4}-s_{2}}{s_{3}-s_{1}}
$$

The standard deviations of subsidence in time $\left(s_{s_{e}}\right)$ as well as the standard deviations for the time factor $\left(s_{c}\right)$ are as follows:

$$
\begin{gathered}
s_{s e}=\frac{s_{s}}{\left(s_{3}+s_{2}\right)-\left(s_{4}+s_{1}\right)} \sqrt{\sum_{i=0}^{i=4}\left(s_{e}-s_{i}\right)^{2}} \\
s_{c}=\frac{s_{s}}{\Delta t} \sqrt{\frac{2}{\left(s_{3}-s_{1}\right)^{2}}+\frac{2}{\left(s_{4}-s_{2}\right)^{2}}}
\end{gathered}
$$

However, it should be noted that measurements are rarely taken when the extraction ceases. According to the presented theoretical solution, the starting point for the description of subsidence after the end of the extraction process can be any measured subsidence in time $t_{i}>T$. In such a case, a solution describing the course of subsidence in time is used for $t_{i}<t$ :

$$
s\left(t>t_{i}\right)=s\left(t_{i}\right)+\Delta s_{e}\left(t_{i}\right) \cdot\left(1-\exp \left[-c\left(t-t_{i}\right)\right]\right),
$$

where

$$
\Delta s_{e}\left(t_{i}\right)=s_{e}-s\left(t_{i}\right)
$$

as mentioned, the function describing the change in residual subsidence over time is described by an exponential function (Equation (3)), which is asymptotic to the value of the expected final subsidence $s_{e}$. This allows us to specify deterministically the expected time span needed for the process of subsidence to end. However, this is closely linked to 
the definition of mining damage, i.e., the moment at which subsidence ends should be determined in a way that the subsidence that may occur after that moment is insignificant regarding the environment, construction works, or changes in water conditions. This value was used as the limit level $\left(\Delta s_{G r}\right)$ for the end of subsidence. Such value should be determined according to the problem, based on existing experience and theoretical considerations.

For example, in agriculture, subsidence affects groundwater levels, which in turn is subject to significant natural fluctuations. According to Knufinke [28], the frequency of precipitation influences the fluctuations of the groundwater level, ranging from 0.5 to $2.0 \mathrm{~m}$ during the year. It can increase to 3.0-4.0 m during long periods of drought or rainfall. Studies carried out by Benning [51] in the Etzel area (Germany) showed that groundwater fluctuations reach an average of $1.0 \mathrm{~m}$. This results in a minimum natural groundwater level fluctuation of ca. $0.5 \mathrm{~m}$ per year. The assumption that a change in groundwater level associated with residual subsidence of $<10 \%$ of the natural minimum fluctuation does not have a significant impact on agriculture and forestry leads to a limit value for residual sedimentation $\Delta s_{G r}=50 \mathrm{~mm}$.

The time when subsidence practically ends is determined by the solution in Equation (12), using Equations (14) and (15):

$$
\begin{gathered}
\Delta t_{i}\left(\Delta s_{G r}\right)=-\frac{1}{c} \ln \frac{\Delta s_{G r}}{s_{e}-s\left(t_{i}\right)}, \\
t_{e}\left(\Delta s_{G r}\right)=t_{i}+\Delta t_{i}\left(\Delta s_{G r}\right)
\end{gathered}
$$

where $s\left(t_{i}\right)$ is the subsidence measured at time $t_{i}$, and $t_{e}\left(\Delta s_{G r}\right)$ is the time needed to achieve the expected (limit) residual subsidence $\Delta s_{G}$.

The uncertainty of the time to reach the residual subsidence limit, determined in this way, is described by Equation (16):

$$
s_{t e}=\frac{1}{c} \sqrt{\left(\Delta t\left(\Delta s_{G r}\right)\right)^{2} \cdot s_{c}^{2}+\frac{s_{s_{e}}^{2}+s_{s}^{2}}{\left(s_{e}-s\left(t_{i}\right)\right)^{2}}} .
$$

The meaning of the symbols is shown in Figure 5.

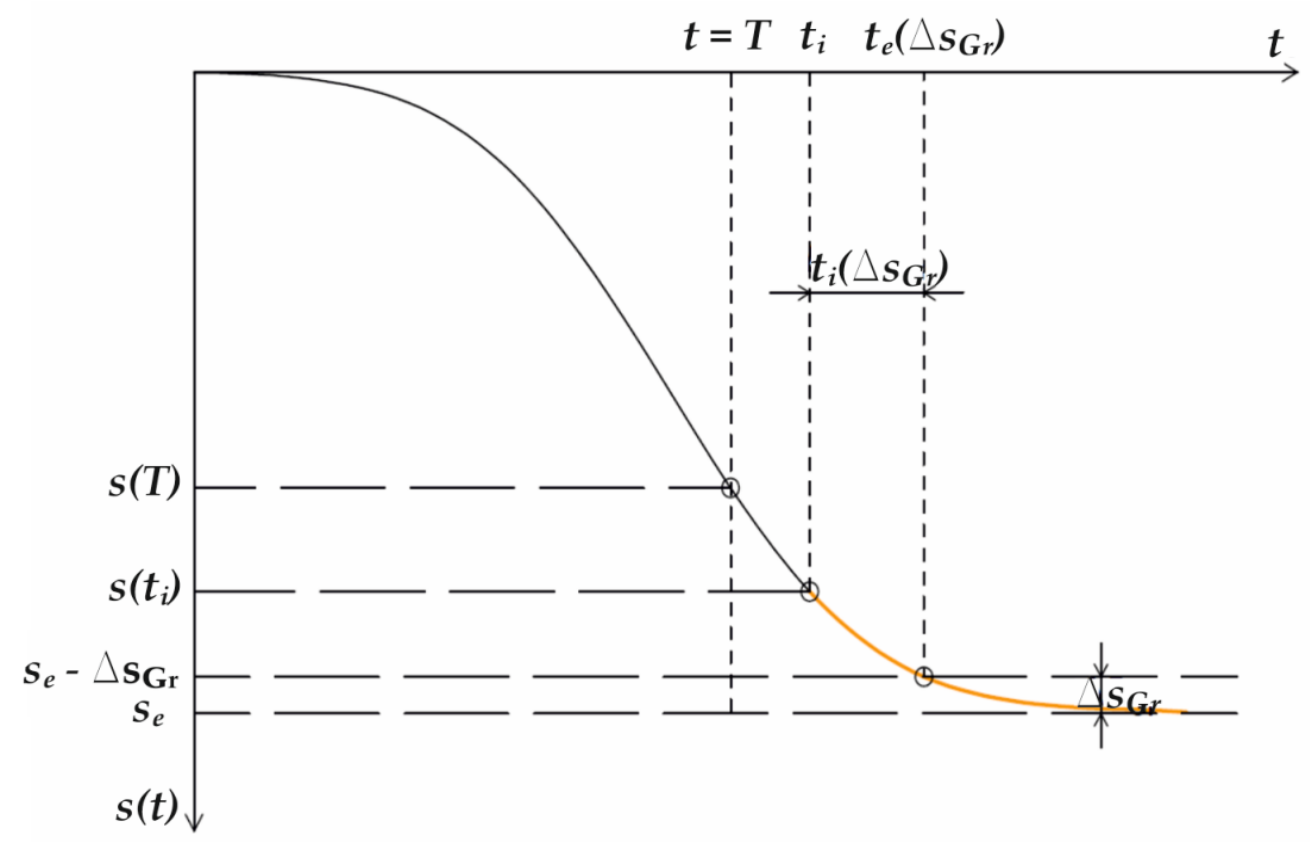

Figure 5. Graphical presentation of how the residual subsidence time $t_{e}\left(\Delta s_{G r}\right)$ is determined for a specific value of $\Delta s_{G r}$. 


\section{Determination of Final Subsidence and Subsidence Time for the Site of a Former Coal Mine Case Study}

The new solutions presented above were used in cooperation with RAG (Germany) to assess future deformations for the area of the former Auguste-Victoria mine, which was closed on 31 December 2015. During the mine's existence, geodetic measurements of surface displacements were carried out using the precision levelling method with an average accuracy of less than $\pm 2.0 \mathrm{~mm}$, with a standard deviation of $2.8 \mathrm{~mm}$. The first observations were carried out as early as 1921, and from 1990 they were conducted regularly at intervals of two years. The observations were led by the German State Office for National Measurements (Landesvermessungsamt NRW) under the so-called levelling measurements net aimed at keeping the altitude network in the whole state of Rhineland Westphalia up to date. Figure 6 shows the area of the ground surface with outlines of the exploitation and the measurement points stabilised on the surface. For the analysis, the authors of the article adopted 10 measurement points in areas where mining operations were ended in different periods (Table 2).

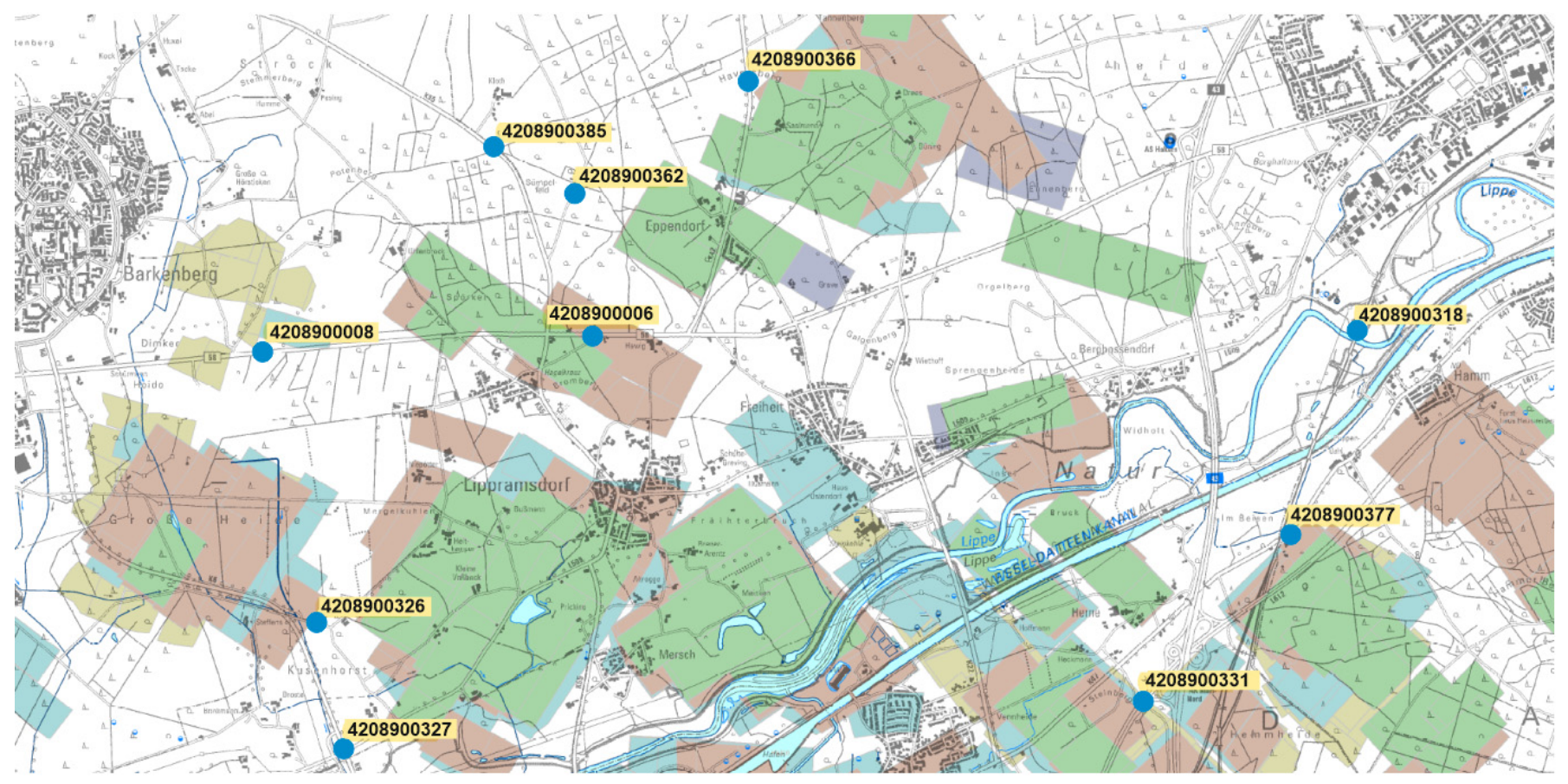

Figure 6. Map of the locations of measuring points in the Auguste-Victoria mine area (violet-exploitation in years 2010-2015, green-exploitation in 2000-2009, pink—exploitation in 1990-1999, blue-exploitation in 1980-1989, and olive-exploitation in 1969-1979).

Table 2. Dates of cessation of exploitation in the areas of specific measurement points.

\begin{tabular}{cc}
\hline Measuring Point Number & Year Exploitation Ended in the Area of the Point \\
\hline 4208900006 & 2009 \\
4208900008 & 1989 \\
4208900318 & 1999 \\
4208900326,4208900327 & 2012 \\
$4208900331,4208900362,4208900366$ & 2015 \\
4208900377 & 2006 \\
4208900385 & 2014 \\
\hline
\end{tabular}

Prognostic calculations of the total final subsidence were carried out, and the time needed for the measuring points to reach the residual subsidence limit was determined. The analyses were based on the solutions presented in the previous chapter using the 
proprietary method. Table 3 shows the values of measured subsidence of measurement points in the last measurement cycles until 2018.

Table 3. The values of the measured subsidence of measurement points $4208900006-4208900327$ in the individual periods of time from the moment when exploitation ceased in the individual areas.

\begin{tabular}{|c|c|c|c|c|c|c|c|c|c|c|}
\hline \multirow[b]{2}{*}{ Year } & \multicolumn{10}{|c|}{ Subsidence for Individual Measuring Points [mm] } \\
\hline & $\begin{array}{c}\text { No. } \\
4208900006\end{array}$ & $\begin{array}{c}\text { No. } \\
4208900008\end{array}$ & $\begin{array}{c}\text { No. } \\
4208900318\end{array}$ & $\begin{array}{c}\text { No. } \\
4208900326\end{array}$ & $\begin{array}{c}\text { No. } \\
4208900327\end{array}$ & $\begin{array}{c}\text { No. } \\
4208900331\end{array}$ & $\begin{array}{c}\text { No. } \\
4208900336\end{array}$ & $\begin{array}{c}\text { No. } \\
4208900362\end{array}$ & $\begin{array}{c}\text { No. } \\
4208900377\end{array}$ & $\begin{array}{c}\text { No. } \\
4208900385\end{array}$ \\
\hline 2002 & - & 795.0 & - & - & - & - & - & - & - & - \\
\hline 2004 & - & 809.0 & - & - & - & - & - & - & - & - \\
\hline 2006 & - & 825.0 & 266.0 & - & - & - & - & - & 2378.0 & - \\
\hline 2008 & 2289.0 & 833.0 & 277.0 & - & - & - & - & - & 2422.0 & - \\
\hline 2010 & 2347.0 & 839.0 & 284.0 & 1554.0 & 750.0 & 4493.0 & - & - & 2446.0 & - \\
\hline 2012 & 2383.0 & 849.0 & 286.0 & 1584.0 & 773.0 & 4538.0 & - & 770.0 & 2467.0 & 242.0 \\
\hline 2014 & 2435.0 & 860.0 & 295.0 & 1599.0 & 784.0 & 4668.0 & 2015.0 & 824.0 & 2489.0 & 267.0 \\
\hline 2016 & 2454.0 & 866.0 & 298.0 & 1604.0 & 785.0 & 4727.0 & 2128.0 & 854.0 & 2503.0 & 279.0 \\
\hline 2018 & 2464.0 & 869.0 & 300.0 & 1609.0 & 789.0 & 4750.0 & 2156.0 & 865.0 & 2511.0 & 283.0 \\
\hline
\end{tabular}

"-" means that in a given period the point was under the influence of active mining.

In order to present the calculation methodology using an example, the authors have included below a detailed description of the solution for the example of the measuring point number 4208900377. For the measurement data in Table 3, calculations were made for the three-point (Equations (3) and (4)) and four-point solution (Equations (7) and (8)). As a result of the calculations, the estimated values of the final subsidence of the residual point and additionally the time factor for individual calculation variants related to the time of measurements (with indicators standard deviations) were obtained:

1. (four-point): measurements carried out in the years: 2008, 2010, 2016, and 2018; $s_{e}=2543.5 \mathrm{~mm} \pm 20.5 \mathrm{~mm}, c=0.1100$ year $^{-1} \pm 0.0279$ year $^{-1}, \Delta t=2$ years;

2. (three-point): measurements carried out in the years: 2010, 2014, and 2018; $s_{\mathrm{e}}=2534.0 \mathrm{~mm} \pm 12.2 \mathrm{~mm}, c=0.1675$ year $^{-1} \pm 0.0428$ year $^{-1}, \Delta t=4$ years;

3. (three-point): measurements carried out in the years: 2006, 2012, and 2018; $s_{\mathrm{e}}=2554.0 \mathrm{~mm} \pm 11.2 \mathrm{~mm}, c=0.1174$ year $^{-1} \pm 0.0141$ year $^{-1}, \Delta t=6$ years.

Performed calculations using the Gauss-Markov equalisation algorithm [52] according to the principle $\underline{v^{T} v} \rightarrow$ min!, where $v$ represents the difference between the modelled values of subsidence and the measured values.

Using all observations of subsidence from 2006 to 2018, they lead to the following results: $s_{\mathrm{e}}=2546.2 \mathrm{~mm} \pm 12.3 \mathrm{~mm}, c=0.1300$ year $^{-1} \pm 0.0157$ year $^{-1}$.

The results of the matching calculations are presented in Table 4 .

Table 4. Results of the subsidence obtained using the Gauss-Markov equalisation algorithm.

\begin{tabular}{cccc}
\hline Year & Measured Subsidence $[\mathrm{mm}]$ & Model Subsidence $[\mathrm{mm}]$ & Difference $(\boldsymbol{v})[\mathrm{mm}]$ \\
\hline 2006 & 2378.00 & 2379.55 & 1.55 \\
2008 & 2422.00 & 2417.71 & -4.29 \\
2010 & 2446.00 & 2447.13 & 1.13 \\
2012 & 2467.00 & 2469.81 & 2.81 \\
2014 & 2489.00 & 2487.30 & -1.70 \\
2016 & 2503.00 & 2500.79 & -2.21 \\
2018 & 2511.00 & 2511.19 & 0.19 \\
\hline
\end{tabular}

The presented differences between the model subsidence calculated after identifying the parameters $s_{e}, c$, and the measured subsidence show that the error in determining a single subsidence is $s_{0}=3.1 \mathrm{~mm}$.

Noting that the mean values of the parameters $s_{e}$ and c calculated using the four and three point methods are $s_{e}=2543.8 \mathrm{~mm}$ and $c=0.1316$ year $^{-1}$.

They are fully consistent with the results obtained on the basis of the GaussMarkov algorithm. 
For further analyses, option 2 was selected due to the calculated values and comparison of the graphs of forecasted subsidence. The predicted values of subsidence are presented in Table 5 and in the diagram showing the course of subsidence (Figure 7).

Table 5. Forecast of subsidence for point 4208900377 after completion of measurements in 2018.

\begin{tabular}{ccc}
\hline Year & Measured Subsidence $[\mathrm{mm}]$ & Calculated Subsidence [mm] \\
\hline 2008 & 2422.00 & 2411.00 \\
2010 & 2446.00 & 2446.00 \\
2012 & 2467.00 & 2471.10 \\
2014 & 2489.00 & 2489.00 \\
2016 & 2503.00 & 2501.80 \\
2018 & 2511.00 & 2511.00 \\
2020 & - & 2517.60 \\
2022 & - & 2522.30 \\
2024 & - & 2525.60 \\
2026 & - & 2528.00 \\
2028 & - & 2529.70 \\
2030 & - & 2531.00 \\
\hline
\end{tabular}

Sign "-" means that measurement was not carried out.

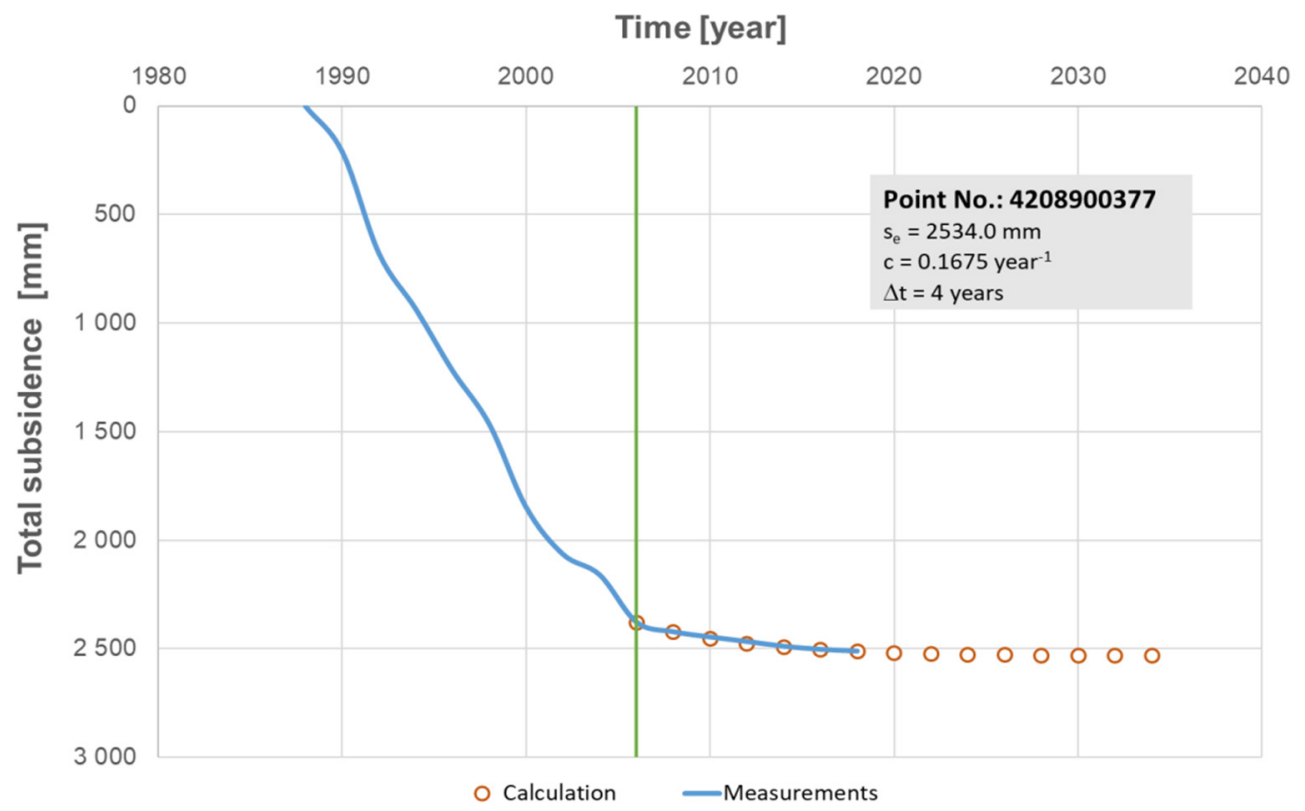

Figure 7. Diagram of the forecasted course of subsidence for point 4208900377 after the end of exploitation (2006).

The last stage of the calculations was to determine the expected time span for subsidence depending on the defined residual subsidence limit $\Delta s_{G r}$. The results are presented in Table 6.

Table 6. Estimated time of subsidence for subsidence limit values.

\begin{tabular}{cc}
\hline$\Delta s_{\mathrm{Gr}}[\mathrm{mm}]^{*}$ & $t_{\mathrm{e}}\left(\Delta \mathbf{s}_{\mathrm{Gr}}\right)$ [years] \\
\hline 100 & - \\
50 & 2013 \\
25 & 2017 \\
10 & 2022 \\
5 & 2027 \\
\hline
\end{tabular}

Sign "-" means that measurement was not carried out * $\Delta s_{G r}<s_{e}-s(t)$. 
Figures 8-10 below show graphical presentation of the results of forecasts for the remaining measurement points shown in Table 3.

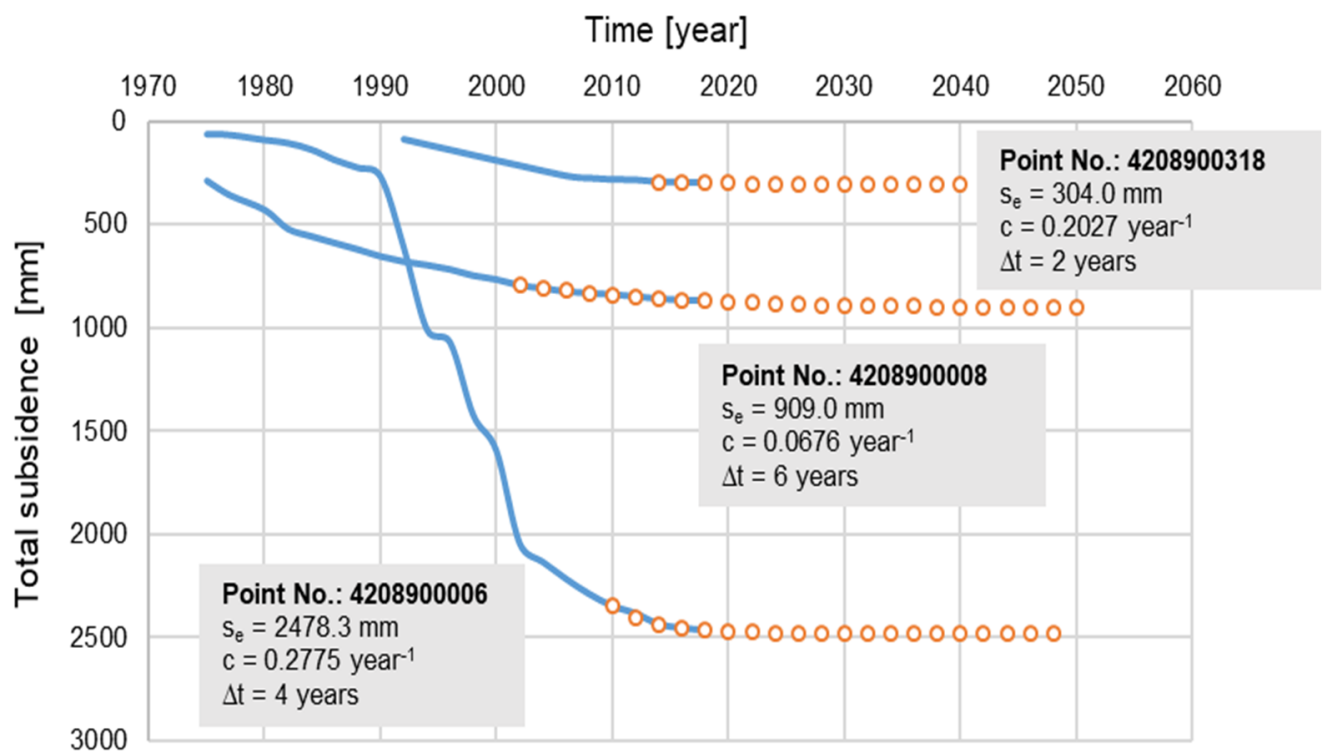

Figure 8. Results of calculations of total subsidence for measurement points 4208900006, 4208900008, and 4208900318 (blue line-measured subsidence; orange markers—predicted residual subsidence).

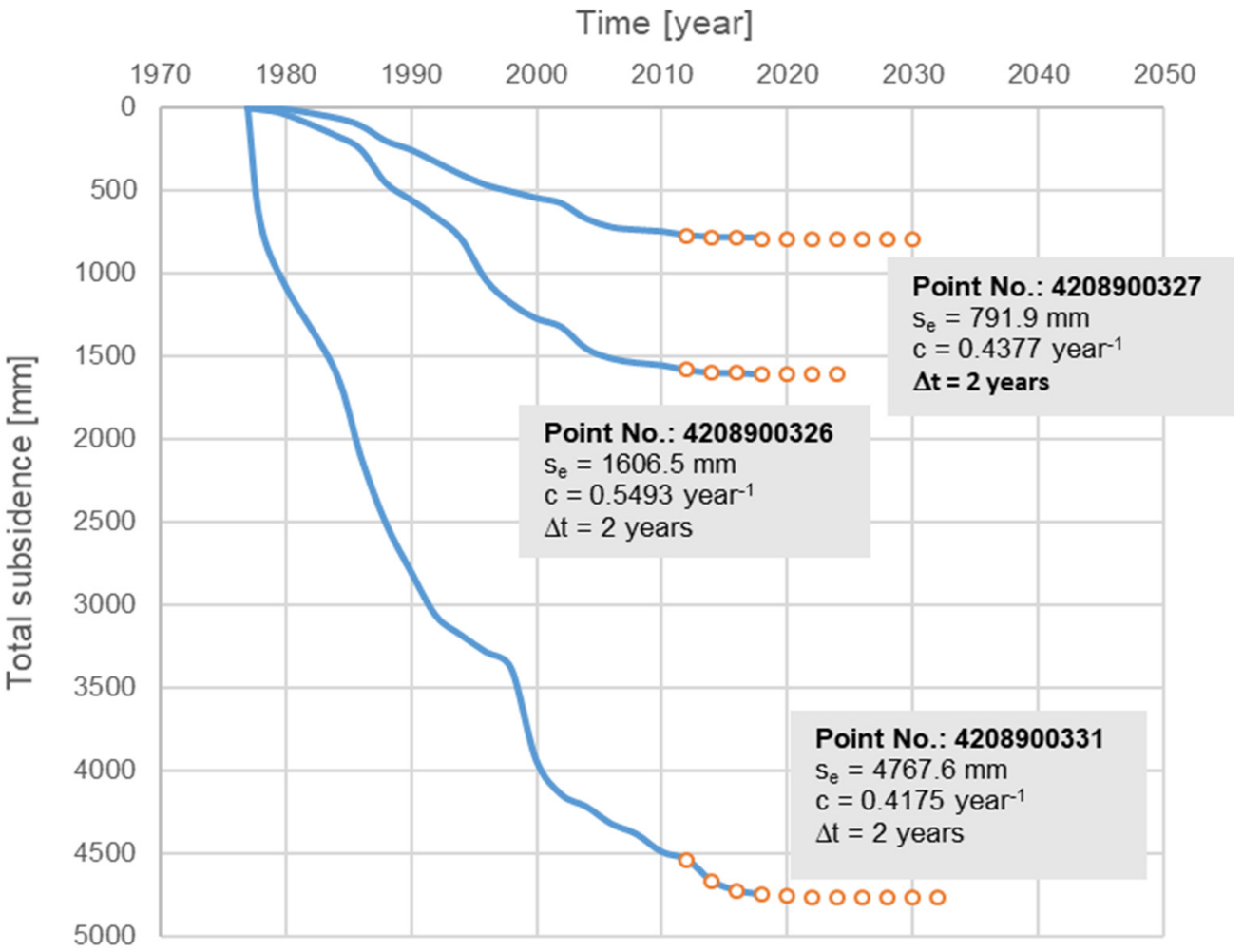

Figure 9. Results of calculations of total subsidence for measurement points 4208900326, 4208900327, and 4208900331 (blue line-measured subsidence; orange markers—predicted residual subsidence).

Additionally, Table 7 presents the estimated subsidence time $t_{e}\left(\Delta s_{G r}\right)$ for the individual measuring points, which depends on the defined residual subsidence limit $\Delta s_{G r}$. 


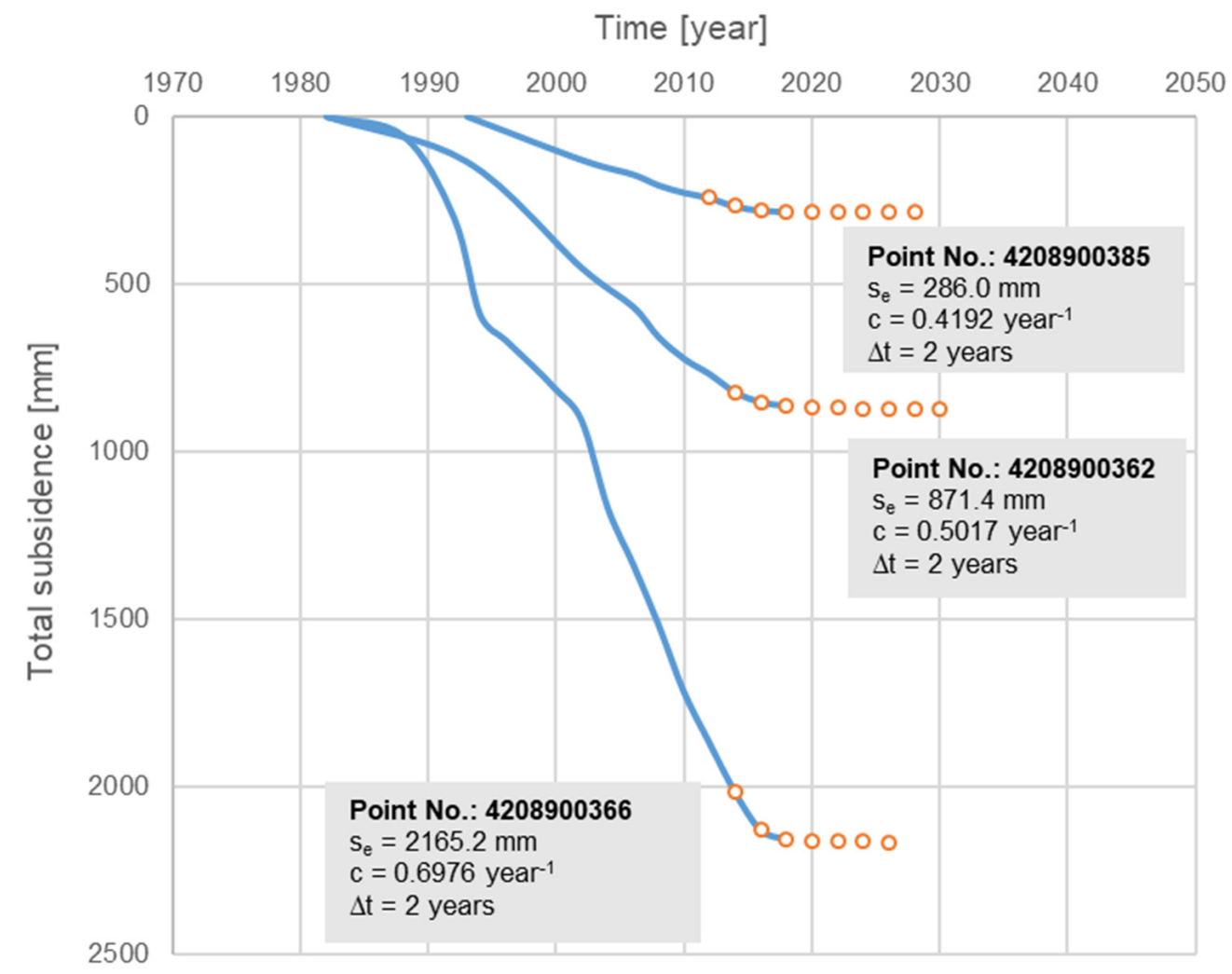

Figure 10. Results of calculations of total subsidence for measurement points 4208900336, 4208900362, and 4208900385 (blue line-measured subsidence; orange markers—predicted residual subsidence).

Table 7. Subsidence time $t_{e}\left(\Delta s_{G r}\right)$ depending on the residual subsidence limit $\Delta s_{G r}$.

\begin{tabular}{|c|c|c|c|c|c|c|c|c|c|}
\hline \multirow[b]{2}{*}{$\Delta s_{G r}[\mathrm{~mm}]$} & \multicolumn{9}{|c|}{$\overline{t_{e}\left(\Delta s_{G r}\right)}$} \\
\hline & $\begin{array}{c}\text { No. } \\
4208900006\end{array}$ & $\begin{array}{c}\text { No. } \\
4208900008\end{array}$ & $\begin{array}{c}\text { No. } \\
4208900318\end{array}$ & $\begin{array}{c}\text { No. } \\
4208900326\end{array}$ & $\begin{array}{c}\text { No. } \\
4208900327\end{array}$ & $\begin{array}{c}\text { No. } \\
4208900331\end{array}$ & $\begin{array}{c}\text { No. } \\
4208900362\end{array}$ & $\begin{array}{c}\text { No. } \\
4208900385\end{array}$ & $\begin{array}{c}\text { No. } \\
4208900366\end{array}$ \\
\hline 100 & 2012 & 2004 & 2004 & 2005 & 2005 & 2014 & 2012 & 2008 & 2015 \\
\hline 50 & 2014 & 2016 & 2006 & 2011 & 2010 & 2016 & 2014 & 2010 & 2016 \\
\hline 25 & 2016 & 2026 & 2010 & 2012 & 2012 & 2018 & 2016 & 2014 & 2017 \\
\hline 10 & 2020 & 2038 & 2014 & 2014 & 2014 & 2020 & 2018 & 2016 & 2018 \\
\hline 5 & 2022 & 2050 & 2018 & 2015 & 2016 & 2022 & 2020 & 2018 & 2020 \\
\hline
\end{tabular}

For residual subsidence limit $\Delta s_{G r}=50 \mathrm{~mm}$, which was specified for agricultural land, subsidence was completed in 2014.

6. Discussion. Evaluation of the Time Function Based on the Results of In Situ Subsidence Measurements after the End of Mining Operations

The analyses presented above have shown that it is possible to forecast the residual subsidence after the end of the operation. On the other hand, the extensive observational material available to the authors allows for the evaluation of the applied time function. The analysis was carried out on the basis of any selected points from the analysed regions of mines located in the Ruhr Basin (Figure 11).

In mining practice, subsidence measurements are rarely performed at the end of a mining operation. For this reason, the starting point for the analyses is the first subsidence measurement made after its completion. Then, Equation (3) takes the form:

$$
s(t)=s\left(t_{1}\right)+\left[s_{e}-s\left(t_{1}\right)\right]\left[1-\exp \left(-c\left(t-t_{1}\right)\right)\right], t \geq T,
$$

where $t_{1}$-time of the first measurement after the end of mining operations and $s\left(t_{1}\right)$ subsidence at the moment $t_{1}$. 


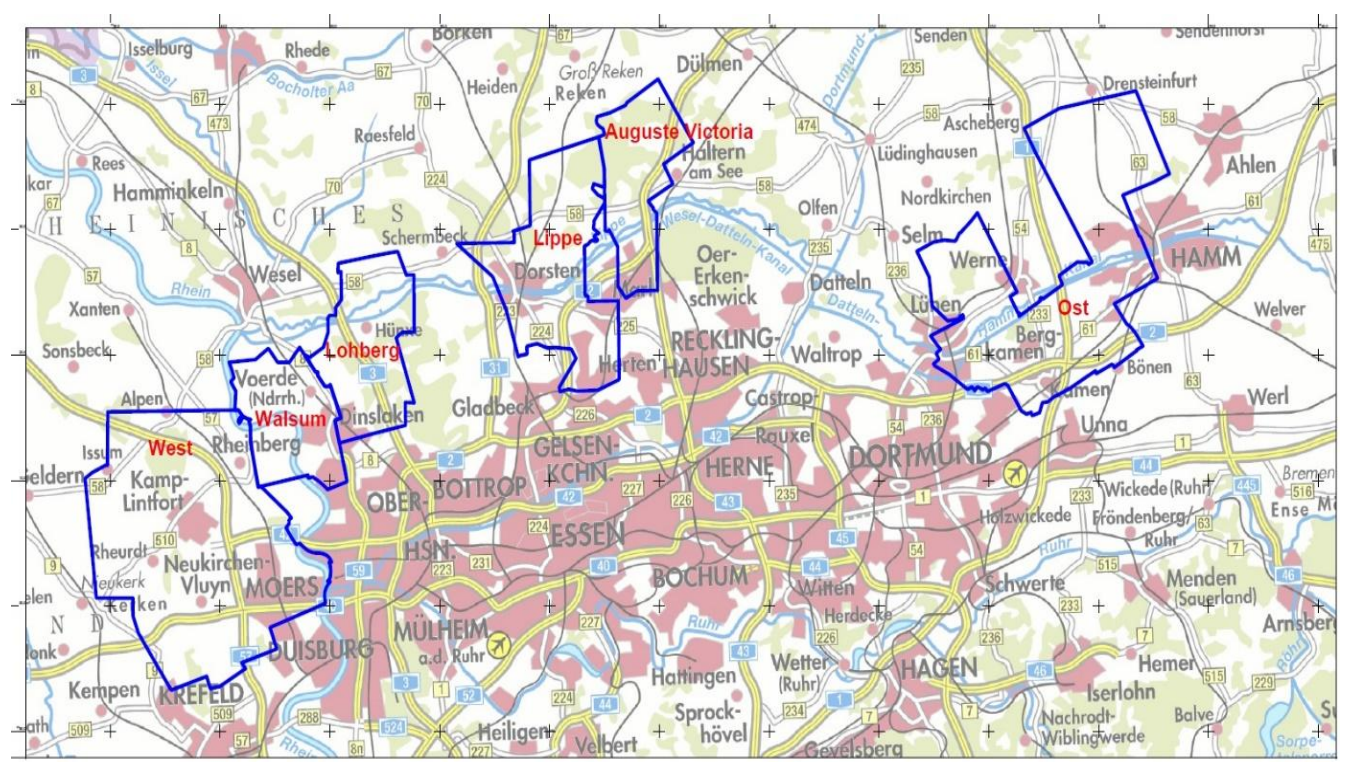

Figure 11. A situational map showing the areas of the mines selected for the analysis.

The evaluation of the $s_{e}$ and $c$ parameters can be carried out using the approximate three- or four-point method and strictly using the Gauss-Markov equalisation algorithm. By transforming the equation, we arrive at:

$$
\frac{s(t)-s\left(t_{1}\right)}{s_{e}-s\left(t_{1}\right)}=\frac{\Delta s(\Delta t)}{\Delta s_{e}}=1-\exp (-c \cdot \Delta t),
$$

where $\Delta t=t-t_{1}$.

Equation (18) leads to a time function of the form:

$$
z(\Delta t)=1-\exp (-c \cdot \Delta t)
$$

where $\Delta t$-time after the end of mining operation (or after observation at time $t_{1}$ ).

The evaluation of the above time function was based on the analysis of the subsidence course after the end of mining operations. The calculation results for six randomly selected individual points in the six analysed regions of the BW West Neu, BW Lippe, BW Ost, BW Walsum, BW Auguste-Victoria, and BW Loberg mines in the Ruhr Area are presented in Table 8 and collectively in Figure 12 .

Table 8. Analysis of residual subsidence for selected points of various mines belonging to the RAG together with the

\begin{tabular}{|c|c|c|c|c|c|c|c|c|c|}
\hline \multirow{2}{*}{ Years } & \multicolumn{3}{|c|}{ BW West Neu (Point 4505900101) } & \multicolumn{3}{|c|}{ BW Lippe (Point 4308900148) } & \multicolumn{3}{|c|}{ BW Ost (Point 4312900232) } \\
\hline & $s\left(t_{i}\right)[\mathrm{mm}]$ & $\frac{\Delta s\left(t_{1}\right)}{\Delta s_{e}}$ & $c \cdot t$ & $s\left(t_{i}\right)[\mathrm{mm}]$ & $\frac{\Delta s\left(t_{1}\right)}{\Delta s_{e}}$ & $c \cdot t$ & $s\left(t_{i}\right)[\mathrm{mm}]$ & $\frac{\Delta s\left(t_{1}\right)}{\Delta s_{e}}$ & $c \cdot t$ \\
\hline 1994 & 2553 & 0.0000 & 0.0000 & - & - & - & - & - & \\
\hline 2000 & 2607 & 0.2795 & 0.3282 & - & - & - & - & - & \\
\hline 2002 & - & - & - & - & - & - & - & - & \\
\hline 2004 & - & - & - & - & - & - & 740 & 0.0000 & 0.0000 \\
\hline 2006 & 2646 & 0.4814 & 0.6564 & - & - & - & 782 & 0.3043 & 0.3590 \\
\hline 2008 & & - & - & - & - & - & 813 & 0.5290 & 0.7180 \\
\hline 2010 & & - & - & 4820 & 0.0000 & 0.0000 & 831 & 0.6594 & 1.0770 \\
\hline 2012 & 2674 & 0.6263 & 0.9846 & 4839 & 0.3333 & 0.4054 & 840 & 0.7246 & 1.4360 \\
\hline 2014 & - & - & - & 4853 & 0.5789 & 0.8108 & 850 & 0.7971 & 1.7950 \\
\hline 2016 & - & - & - & 4861 & 0.7193 & 1.2162 & 862 & 0.8841 & 2.1540 \\
\hline 2018 & - & - & - & - & - & - & 865 & 0.9058 & 2.5130 \\
\hline
\end{tabular}
determination of time coefficients. 
Table 8. Cont.

\begin{tabular}{|c|c|c|c|c|c|c|c|c|c|}
\hline \multirow{2}{*}{ Years } & \multicolumn{3}{|c|}{ BW Walsum (Point 4405900174) } & \multicolumn{3}{|c|}{ BW Auguste-Victoria (Point 4208900008) } & \multicolumn{3}{|c|}{ BW Loberg (Point 4406900209) } \\
\hline & $s\left(t_{i}\right)[\mathrm{mm}]$ & $\frac{\Delta s\left(t_{1}\right)}{\Delta s_{e}}$ & $c t$ & $s\left(t_{i}\right)[\mathrm{mm}]$ & $\frac{\Delta s\left(t_{1}\right)}{\Delta s_{e}}$ & $c t$ & $s\left(t_{i}\right)[\mathrm{mm}]$ & $\frac{\Delta s\left(t_{1}\right)}{\Delta s_{e}}$ & $c t$ \\
\hline 1994 & - & - & - & - & - & - & - & - & - \\
\hline 2000 & 2171 & 0.0000 & 0.0000 & - & - & - & - & - & - \\
\hline 2002 & - & - & - & 795 & 0.0000 & 0.0000 & - & - & - \\
\hline 2004 & - & - & - & 809 & 0.1228 & 0.1352 & - & - & - \\
\hline 2006 & 2281 & 0.3714 & 0.4470 & 825 & 0.2632 & 0.2704 & 1274 & 0.0000 & 0.0000 \\
\hline 2008 & - & - & - & 833 & 0.3333 & 0.4056 & 1314 & 0.1899 & 0.2164 \\
\hline 2010 & - & - & - & 839 & 0.3860 & 0.5408 & 1348 & 0.3514 & 0.4328 \\
\hline 2012 & 2346 & 0.5908 & 0.8940 & 849 & 0.4737 & 0.6760 & 1371 & 0.4606 & 0.6492 \\
\hline 2014 & - & - & - & 860 & 0.5702 & 0.8112 & 1396 & 0.5793 & 0.8656 \\
\hline 2016 & - & - & - & 866 & 0.6228 & 0.9464 & 1410 & 0.6458 & 1.0820 \\
\hline 2018 & 2391 & 0.7427 & 1.3410 & 869 & 0.6491 & 1.0816 & 1427 & 0.7265 & 1.2984 \\
\hline
\end{tabular}

Sign "-" means that measurement was not carried out.

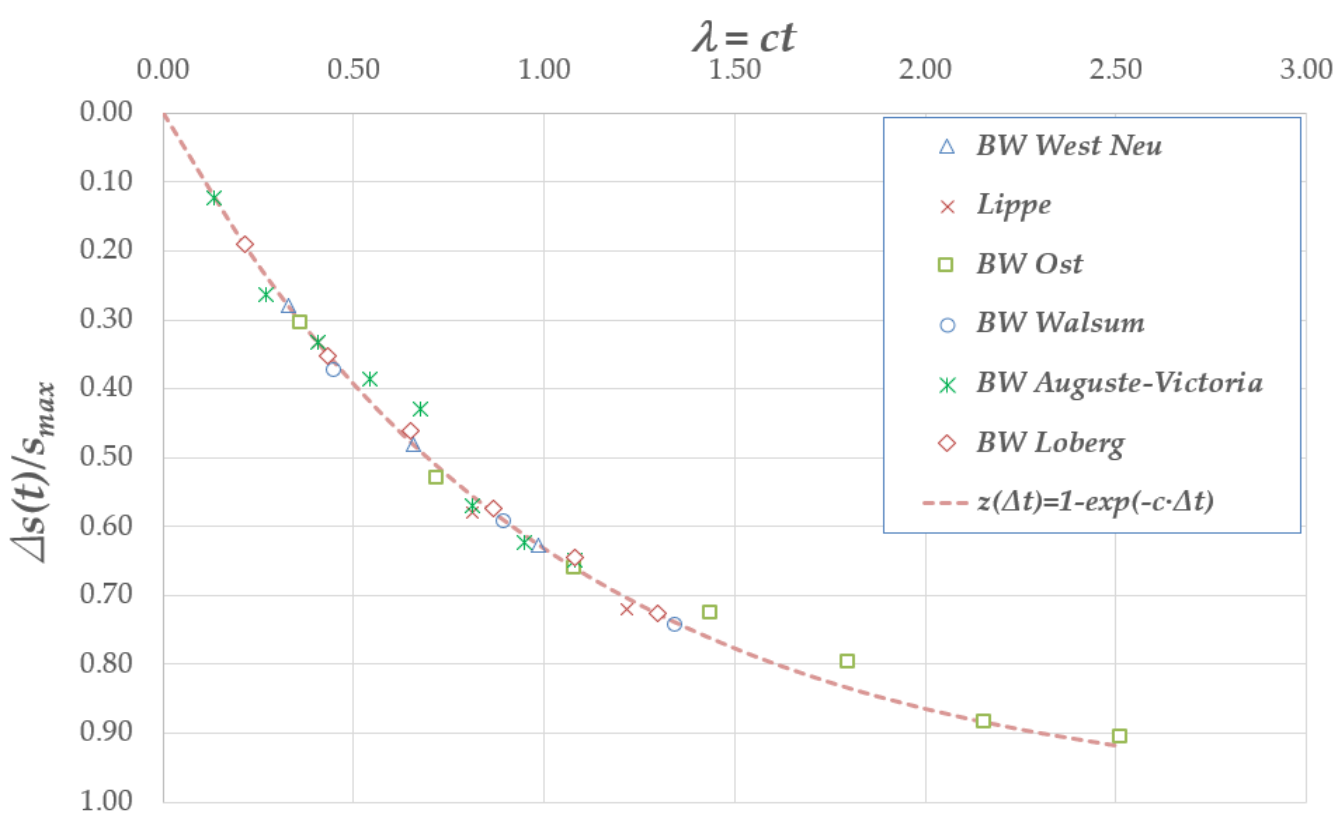

Figure 12. Graph of the residual subsidence of sample points in time for six different mines of the German company RAG.

For each analysed area of mines, the values of $s_{e}$ and $c$ parameters were determined, adopting the methodology presented in the article:

- $\quad$ BW West Neu: $s_{e}=2746.2 \mathrm{~mm} \pm 20.6 \mathrm{~mm}, c=0.0547$ year $^{-1} \pm 0.0086$ year $^{-1}$, $\Delta t=6$ years;

- $\quad$ BW Lippe: $s_{e}=4877.0 \mathrm{~mm} \pm 6.1 \mathrm{~mm}, c=0.2027$ year $^{-1} \pm 0.1318$ year $^{-1}, \Delta t=2$ years;

- BW Ost: $s_{e}=878.0 \mathrm{~mm} \pm 5.6 \mathrm{~mm}, c=0.1795$ year $^{-1} \pm 0.0184$ year $^{-1}, \Delta t=2$ years;

- BW Walsum: $s_{e}=2467.2 \mathrm{~mm} \pm 11.6 \mathrm{~mm}, c=0.0745$ year $^{-1} \pm 0.0057$ year $^{-1}, \Delta t=6$ years;

- $\quad$ BW Auguste-Victoria: $s_{e}=909.0 \mathrm{~mm} \pm 17.2 \mathrm{~mm}, c=0.0676$ year $^{-1} \pm 0.0157$ year $^{-1}$, $\Delta t=2$ years;

- $\quad$ BW Loberg: $s_{e}=1484.6 \mathrm{~mm} \pm 27.4 \mathrm{~mm}, c=0.1082$ year $^{-1} \pm 0.0212$ year $^{-1}, \Delta t=2$ years.

Table 8 summarises the calculated values of $\frac{\Delta s\left(t_{1}\right)}{\Delta s_{\rho}}$ and $c \cdot t$ for selected points of six mines belonging to the RAG company, where $\Delta s_{e}=s_{e}-s\left(t_{1}\right)$.

Based on the data presented in Table 8 , a graph of the time function was prepared (Figure 12). 


\section{Summary}

Forecasting the residual movements of the land surface caused by mining operations is essential for determining the period of measurements and for assessing the potential mining damage and the possibility of reusing the land. The experiences of the international scientists cited at the beginning of the article do not give a clear indication of the time span that should be taken to determine long-term residual subsidence. The presented calculation example for the actual mine owned by RAG (Auguste-Victoria), based on the author's solution, shows that in some cases this time may continue for several years. Observations of the measurements and results of calculations indicate that after the closure of the Auguste-Victoria mine, the measured differences in subsidence in the 2014-2016 and 2016-2018 measurement periods are clearly decreasing compared to the previous period. The predicted average increase in subsidence over the period 2018-2020 is about $5 \mathrm{~mm}$, and the expected value of maximum subsidence will be at about $20 \mathrm{~mm}$, i.e., $10 \mathrm{~mm}$ per year. These values are not significant for building structures, while for agriculture, assuming a residual subsidence limit of $\Delta s_{G r}=50 \mathrm{~mm}$, it was estimated that surface movements ended in 2014.

Author Contributions: Conceptualization, K.T., A.S., R.M. and M.D.; methodology, A.S., K.T., R.M. and M.D.; software, K.T., A.S., R.M. and M.D.; validation, K.T., A.S., R.M., S.H., M.D., J.R. and F.W.; formal analysis, K.T., A.S., R.M. and M.D.; investigation, K.T., A.S., R.M., S.H., M.D., J.R. and F.W.; resources, A.S., S.H. and F.W.; writing—original draft preparation, K.T and A.S.; writing-review and editing, K.T., R.M., A.S., M.D. and J.R.; visualization, K.T., R.M. and A.S.; supervision, A.S., K.T. and S.H.; project administration, A.S., K.T. and S.H. All authors have read and agreed to the published version of the manuscript.

Funding: The research has been partially carried out under the Research Fund of IMG PAN under agreement nr 5 .

Data Availability Statement: Not applicable.

Acknowledgments: The work was partially carried out in 2021 as part of the statutory work carried out at the IMG PAN in Krakow, financed by the Ministry of Education and Science.

Conflicts of Interest: The authors declare no conflict of interest.

\section{References}

1. Durucan, S.; Korre, A.; Munoz-Melendez, G. Mining life cycle modelling: A cradle-to-gate approach to environmental management in the minerals industry. J. Clean. Prod. 2006, 14, 1057-1070. [CrossRef]

2. Fathi Salmi, E.; Nazem, M.; Karakus, M. Numerical analysis of a large landslide induced by coal mining subsidence. Eng. Geol. 2017, 217, 141-152. [CrossRef]

3. Govindan, K.; Kannan, D.; Shankar, K.M. Evaluating the drivers of corporate social responsibility in the mining industry with multi-criteria approach: A multi-stakeholder perspective. J. Clean. Prod. 2014, 84, 214-232. [CrossRef]

4. Gutiérrez, F.; Zarroca, M.; Linares, R.; Roqué, C.; Carbonel, D.; Guerrero, J.; McCalpin, J.P.; Comas, X.; Cooper, A.H. Identifying the boundaries of sinkholes and subsidence areas via trenching and establishing setback distances. Eng. Geol. 2018, 233, 255-268. [CrossRef]

5. Villegas, T.; Nordlund, E.; Dahnér-Lindqvist, C. Hangingwall surface subsidence at the Kiirunavaara Mine, Sweden. Eng. Geol. 2011, 121, 18-27. [CrossRef]

6. Cui, X.; Miao, X.; Yang, S.; Liu, H.; Song, Y.; Liu, H.; Hu, X. Others Improved prediction of differential subsidence caused by underground mining. Int. J. Rock Mech. Min. Sci. 2000, 37, 615-627. [CrossRef]

7. National Coal Board. Subsidence Engineer's Handbook; The Board: London, UK, 1971.

8. Keinhorst, H. Die Berechnung der Bodensenkungen im Emschergebiet. In 25 Jahre der Emschergenossenschaft 1900-1925; Ministerium fur Umwelt, Landwirtschaft, Natur- und Verbraucherschutz des Landes Nordrhein-Westfalen: Essen, Germany, 1925.

9. Knothe, S. Równanie profilu ostatecznie wykształconej niecki osiadania. Arch. Górnictwa Hut. 1953, 1, 22-38.

10. Rahmati, O.; Golkarian, A.; Biggs, T.; Keesstra, S.; Mohammadi, F.; Daliakopoulos, I.N. Land subsidence hazard modeling: Machine learning to identify predictors and the role of human activities. J. Environ. Manag. 2019, 236, 466-480. [CrossRef]

11. Walker, J.S. Case Study of the Effects of Longwall Mining Induced Subsidence on Shallow Ground Water Sources in the Northern Appalachian Coalfield; US Department of the Interior, Bureau of Mines: Pittsburgh, PA, USA, 1988; Volume 9198.

12. Tong, L.; Liu, L.; Qiu, Y.; Liu, S. Tunneling in abandoned coal mine areas: Problems, impacts and protection measures. Tunn. Undergr. Sp. Technol. 2013, 38, 409-422. [CrossRef] 
13. Rusek, J. The Point Nuisance Method as a Decision-Support System Based on Bayesian Inference Approach. Arch. Min. Sci. 2020, 65, 117-127. [CrossRef]

14. Krzemień, A.; Suárez Sánchez, A.; Riesgo Fernández, P.; Zimmermann, K.; González Coto, F. Towards sustainability in underground coal mine closure contexts: A methodology proposal for environmental risk management. J. Clean. Prod. 2016, 139, 1044-1056. [CrossRef]

15. Laurence, D. Optimisation of the mine closure process. J. Clean. Prod. 2006, 14, 285-298. [CrossRef]

16. Mishra, S.K.; Hitzhusen, F.J.; Sohngen, B.L.; Guldmann, J.-M. Costs of abandoned coal mine reclamation and associated recreation benefits in Ohio. J. Environ. Manag. 2012, 100, 52-58. [CrossRef]

17. Misa, R.; Sroka, A.; Tajduś, K.; Dudek, M. Analytical design of selected geotechnical solutions which protect civil structures from the effects of underground mining. J. Sustain. Min. 2019, 18, 1-7. [CrossRef]

18. Al Heib, M.; Nicolas, M.; Noirel, J.F.; Wojtkowiak, F. Residual subsidence analysis after the end of coal mine work Example from Lorraine Colliery, France. In Proceedings of the Post-Mining, Nancy, France, 16-17 November 2005.

19. Guéguen, Y.; Deffontaines, B.; Fruneau, B.; Al Heib, M.; de Michele, M.; Raucoules, D.; Guise, Y.; Planchenault, J. Monitoring residual mining subsidence of Nord/Pas-de-Calais coal basin from differential and Persistent Scatterer Interferometry (Northern France). J. Appl. Geophys. 2009, 69, 24-34. [CrossRef]

20. Cała, M.; Tajduś, A.; Andrusikiewicz, W.; Kowalski, M.; Kolano, M.; Stopkowicz, A.; Cyran, K.; Jakóbczyk, J. Long term analysis of deformations in salt mines: Kłodawa Salt Mine case study, central Poland. Arch. Min. Sci. 2017, 62, 565-577. [CrossRef]

21. Hoek, E. Surface and Underground Project Case Histories: Comprehensive Rock Engineering: Principles, Practice and Projects; Elsevier: Amsterdam, The Netherlands, 2016; Volume 5.

22. Bell, F.G.; Bullock, S.E.T.; Hälbich, T.F.j.; Lindsay, P. Environmental impacts associated with an abandoned mine in the Witbank Coalfield, South Africa. Int. J. Coal Geol. 2001, 45, 195-216. [CrossRef]

23. Gray, R.E.; Bruhn, R.W.; Turka, R.J. Study and Analysis of Surface Subsidence over the Mined Coal Bed; GAI Consultants Inc.: Springfield, IL, USA, 1977.

24. Vervoort, A.; Declercq, P.-Y. Surface movement above old coal longwalls after mine closure. Int. J. Min. Sci. Technol. 2017, 27, 481-490. [CrossRef]

25. Niemczyk, O. Bergschadenkunde-Investigation of subsidence damage caused by mining. Verlag Glückauf 1949, $27,291$.

26. Flaschentrager, H. Considerations on ground movement phenomena based on observations made in the left bank Lower Rhine region. In Proceedings of the European Congress on Ground Movement, Leeds, UK, 9-12 April 1957; pp. 58-73.

27. Czubik, E. Über die zeitliche Entwicklung des Senkungsablaufes an der Tagesoberfläche beim Abbau von Steinkohlenflözen. Berg-Und Hütten-Männische Mon. 1971, 69, 293-301.

28. Knufinke, P. Zum Phänomen lokaler Höhenänderungen an der Tagesoberfläche. In Proceedings of the IX Congress ISM, Praha, Czech Republic, 18-22 April 1994.

29. Blachowski, J.; Cacon, S.; Milczarek, W. Analysis of post-mining ground deformations caused by underground coal extraction in complicated geological conditions. Acta Geodyn. Geomater. 2009, 6, 351-357.

30. Głowacki, T.; Milczarek, W. Powierzchniowe deformacje wtórne dawnych terenów górniczych. Min. Sci. 2013, 20 , 39-55.

31. Schäfer, A. Zur Verteilung der Bodenbewegungen an der Tagesoberfläche nach Grubenwasseranstieg in einer Steinkohlenlagerstätte. In Proceedings of the Bergbau, Energie und Rohstoffe, Tagungsband, Freiberg, Germany, 7-9 October 2015; pp. 158-170.

32. Lein, C. Ein Beitrag zu Möglichen Senkungen in Tagesnahen Abbau-en bei Grubenwasseranstieg im Saarrevier; Diplomarbeit, TU Bergakademie Freiberg: Freiberg, Germany, 2015.

33. North Fork Coal Program: Environmental Impact Statement; Bureau of Land Menagement USDI: Grand Junction, CO, USA, 1999.

34. Raucoules, D.; Le Mouelic, S.; Carnec, C.; Guise, Y. Monitoring post-mining subsidence in the Nord-Pas-de-Calais coal basin (France): Comparison between interferometric SAR results and levelling. Geocarto Int. 2008, 23, 287-295. [CrossRef]

35. Borecki, M.; Knothe, S. Ochrona Powierzchni Przed Szkodami Górniczymi; Wydawnictwo Śląsk: Katowice, Poland, 1980.

36. Wagner, D. Zanikanie obniżania powierzchni śródmieścia Bytomia w latach 2015-2018 po zakończonej eksploatacji przez KWK Centrum. Przeglad Górniczy 2019, 75, 33-39.

37. Aissaoui, K. Amélioration de La Prévision Des Affaissements Dans Les Mines à l'aide Des Approches Empiriques, Numériques et Analytiques. Ph.D. Thesis, Laborotoire Environnement, Geomecanique, Ouvrages (LAEGO), Nancy, France, 1999.

38. Lee, D.-K.; Mojtabai, N.; Lee, H.-B.; Song, W.-K. Assessment of the influencing factors on subsidence at abandoned coal mines in South Korea. Environ. Earth Sci. 2013, 68, 647-654. [CrossRef]

39. Knothe, S. Effect of time on formation of basin subsidence. Arch. Min. Steel Ind. 1953, 1, 1-7.

40. Trojanowski, K. Zagadnienie wpływu czynników czasu i postępu eksploatacji górniczej na przebieg procesu ruchów w świetle badań geodezyjnych. Pr. Kom. Górniczo-Geodezyjnej PAN. Geod. 1973, 1, 51-62.

41. Schober, F.; Sroka, A. Die Berechnung von Bodenbewegungen über Kavernen unter Berücksichtigung des zeitlichen Konvergenzund Gebirgsverhaltens. Kali Und Steinsalz 1983, 8, 352-358.

42. Sroka, A. Schriftenreihe Lagerstättenerfassung und -darstellung, Bodenbewegungen und Bergschäden. In Proceedings of the Kolloquium 80 Jahre Institut für Markscheide- und Bergschadenkunde der Montanuniversität Leoben, Leoben, Austria, 15-16 November 1984; pp. 103-132.

43. Liu, X.; Wang, J.; Guo, J.; Yuan, H.; Li, P. Time function of surface subsidence based on Harris model in mined-out area. Int. J. Min. Sci. Technol. 2013, 23, 245-248. [CrossRef] 
44. Hu, Q.; Deng, X.; Feng, R.; Li, C.; Wang, X.; Jiang, T. Model for calculating the parameter of the Knothe time function based on angle of full subsidence. Int. J. Rock Mech. Min. Sci. 2015, 100, 19-26. [CrossRef]

45. Jarosz, A.; Karmis, M.; Sroka, A. Subsidence development with time-Experiences from longwall operations in the Appalachian coalfield. Int. J. Min. Geol. Eng. 1990, 8, 261-273. [CrossRef]

46. Sroka, A.; Knothe, S.; Tajduś, K.; Misa, R. Underground exploitations inside safety pillar shafts when considering the effective use of a coal deposit. Gospod. Surowcami Miner. Miner. Resour. Manag. 2015, 31. [CrossRef]

47. Sroka, A.; Knothe, S.; Tajduś, K.; Misa, R. Point Movement Trace Vs. The Range Of Mining Exploitation Effects in the Rock Mass. Arch. Min. Sci. 2015, 60. [CrossRef]

48. Cui, X.; Zhao, Y.; Wang, G.; Zhang, B.; Li, C. Calculation of Residual Surface Subsidence Above Abandoned Longwall Coal Mining. Sustainability 2020, 12, 1528. [CrossRef]

49. Sroka, A. Zeiträumliche Lösung der Theorie von Knothe. Polnische Akademie der Wissenschaften; Geodäsie Heft 24: Krakau, Poland, 1978.

50. Bartosik-Sroka, T.; Pielok, J.; Sroka, A. Analitycal method of the time coefficient determination emloying results of periodical survay of the surface and strata subsidence. Pr. Kom. Górniczo-Geologicznej. Geod. 1981, 1, 51-62.

51. Benning, H.-J. Kavernenspeicher Etzel. Auswirkungsanalyse für Insgesamt 99 Kavernen; DMT: Essen, Germany, 2018.

52. Niemeier, W. Ausgleichungsrechnung: Eine Einführung für Studierende und Praktiker des Vermessungs und Geoinformationswesens; Walter de Gruyter: Berlin, Germany; New York, NY, USA, 2002. 